\title{
Global validation of SCIAMACHY limb ozone data (versions 2.9 and 3.0, IUP Bremen) using ozonesonde measurements
}

\author{
J. Jia, A. Rozanov, A. Ladstätter-Weißenmayer, and J. P. Burrows \\ Institute of Environmental Physics, Bremen, Germany \\ Correspondence to: J. Jia (jia@iup.physik.uni-bremen.de)
}

Received: 13 March 2015 - Published in Atmos. Meas. Tech. Discuss.: 13 May 2015

Revised: 24 July 2015 - Accepted: 7 August 2015 - Published: 21 August 2015

\begin{abstract}
In this paper, the latest SCIAMACHY limb ozone scientific vertical profiles, namely the current V2.9 and the upcoming V3.0, are extensively compared with ozonesonde data from the World Ozone and Ultraviolet Radiation Data Centre (WOUDC) database. The comparisons are made on a global scale from 2003 to 2011, involving 61 sonde stations. The retrieval processors used to generate V2.9 and V3.0 data sets are briefly introduced. The comparisons are discussed in terms of vertical profiles and stratospheric partial columns. Our results indicate that the V2.9 ozone profile data between 20 and $30 \mathrm{~km}$ are in good agreement with ground-based measurements, with less than $5 \%$ relative differences in the latitude range of $90^{\circ} \mathrm{S}-40^{\circ} \mathrm{N}$ (with the exception of the tropical Pacific region, where an overestimation of more than $10 \%$ is observed), which corresponds to less than $5 \mathrm{DU}$ partial-column differences. In the tropics the differences are within $3 \%$. However, this data set shows a significant underestimation northwards of $40^{\circ} \mathrm{N}$ (up to $\sim 15 \%$ ). The newly developed V3.0 data set reduces this bias to below $10 \%$ while maintaining a good agreement southwards of $40^{\circ} \mathrm{N}$ with slightly increased relative differences of up to $5 \%$ in the tropics.
\end{abstract}

\section{Introduction}

Stratospheric ozone is one of the most important trace gases in the atmosphere. It is well known as an absorber of UV radiation, thereby protecting the biosphere from being damaged by shortwave electromagnetic radiation, and it simultaneously plays a key role in determining the temperature structure of the atmosphere (Read, 1988). Retrieving stratospheric ozone profiles with a high accuracy is not only im- portant for stratospheric ozone studies but also a requirement for the establishment of a long-term essential climate variable data record. To achieve this goal, ground-based, balloon-borne, airborne and satellite instruments have been used to monitor ozone abundances in the atmosphere during the last decades. For satellite instruments, different observation techniques including solar/stellar occultation measurements (e.g., SAGE - Stratospheric Aerosol and Gas Experiment (McCormick et al., 1989); HALOE - Halogen Occultation Experiment (Russell et al., 1994); ACE - Atmospheric Chemistry Experiment (McElroy et al., 2007); GOMOS Global Ozone Monitoring by Occultation of Stars (Bertaux et al., 2010)), limb scatter/emission measurements (e.g., MLS - Microwave Limb Sounder (Waters et al., 2006); MIPAS - Michelson Interferometer for Passive Atmospheric Sounding (Fischer et al., 2008); OSIRIS - Optical Spectrograph and InfraRed Imager System (Llewellyn et al., 2004)) and nadir measurements (e.g., GOME/GOME2 - Global Ozone Monitoring Experiment (Burrows et al., 1999; Callies et al., 2000); OMI - Ozone Monitoring Instrument (Levelt et al., 2006); IASI - Infrared Atmospheric Sounding Interferometer (Clerbaux et al., 2009)) are used (see, e.g., Sofieva et al., 2013; Hassler et al., 2014, and references therein). The passive imaging spectrometer used in this study, SCIAMACHY (SCanning Imaging Absorption spectroMeter for Atmospheric CartograpHY), provided vertical distributions of atmospheric trace gases by employing the limb-scattering measurement technique (Burrows et al., 1995; Bovensmann et al., 1999).

In this paper we discuss the vertical ozone profiles retrieved from SCIAMACHY limb measurements at IUP Bremen (Institute of Environmental Physics, University of Bremen, Germany). The error budget typical for the limb ozone 
V2.5 data set was reported by Rahpoe et al. (2013). Previous validation activities done by Mieruch et al. (2012) with respect to other satellite instruments showed an agreement of better than $10 \%$ and often within $5 \%$ between 20 and $50 \mathrm{~km}$, with a high bias below $20 \mathrm{~km}$ explained by the presence of high convective clouds. Tegtmeier et al. (2013) performed an intercomparison of vertically resolved monthly zonal mean ozone climatologies from 18 limb-viewing satellite instruments operated between 1978 and 2010, including SCIAMACHY observations. The agreement was quite good in the middle stratosphere, with maximum differences of up to $5 \%$. The climatologies derived from SCIAMACHY were found to show a positive bias of up to $+10 \%$ in the tropical and midlatitude upper stratosphere (5-1 hPa).

The current SCIAMACHY data set distributed by IUP Bremen is V2.9. Our comparisons (unpublished) of this data set to ozonesondes showed a severe underestimation of the ozone concentration in the northern high latitudes, with a systematic bias of up to $\sim 15 \%$ between 15 and $30 \mathrm{~km}$. The reason for that is believed to be the instrumental stray light occurring at small relative azimuth angles (sun is close to the instrument field of view) typical for the measurements at high northern latitudes. At these angles, for a 10:00-Equatorcrossing-time instrument at the descending node, the scattering of extraterrestrial solar radiation from the platform could most likely baffles into the instrument field of view, which influences the measurement results. To eliminate the observed negative bias, a new version of SCIAMACHY ozone limb data, V3.0, has been developed. As demonstrated by the validation with ozonesondes, significant improvements have been achieved.

Here, we present validation results comprising 10 years of SCIAMACHY limb data of versions V2.9 and V3.0 using globally distributed data from ozonesondes. The comparisons of SCIAMACHY V2.9 profiles with other satellite data sets have also been published recently (Rahpoe et al., 2015). In this comparison, 61 ozonesonde stations from the WOUDC (World Ozone and Ultraviolet Radiation Data Centre) as well as SHADOZ (Southern Hemisphere ADditional OZonesondes) databases are involved, covering a wide latitude range from $82.5^{\circ} \mathrm{N}$ to $70.6^{\circ} \mathrm{S}$ (see Table 1). The validation includes vertical profile and stratospheric partial-column comparisons. In Sect. 2 the algorithms used and the limitations of both SCIAMACHY limb retrievals are discussed. The methodologies of the limb-sonde comparisons are presented in Sect. 3. In Sect. 4 the statistical analysis of the poleto-pole comparison results is shown, discussed and summarized.

\section{SCIAMACHY limb ozone retrieval}

\subsection{SCIAMACHY instrument}

The SCIAMACHY instrument operated from August 2002 to April 2012 on board the European satellite Envisat (Burrows et al., 1995; Bovensmann et al., 1999). Envisat operated in a sun-synchronous, near-polar orbit with a local equatorial overpass time at around 10:00. at the descending node. SCIAMACHY was a passive spectrometer designed to measure radiances in eight spectral channels covering a wide range from 214 to $2384 \mathrm{~nm}$ with a moderate spectral resolution of $0.21-1.56 \mathrm{~nm}$. The ozone retrieval algorithm employed in this study uses measurements in the Hartley and Chappuis absorption bands in SCIAMACHY special channels 1 (214-314 nm), 3 (392-605 nm) and 4 (598-790 nm).

SCIAMACHY performed observations in three viewing modes: nadir, limb and solar/lunar occultation. In limbviewing geometry, SCIAMACHY observed the atmosphere with the line of sight pointed tangentially to the Earth's surface, with a field of view of $110 \mathrm{~km}$ horizontally and $2.6 \mathrm{~km}$ vertically at the tangent point. A limb measurement sequence started from $3 \mathrm{~km}$ below the horizon $(0 \mathrm{~km}$ after October 2010) and continued with a vertical scan up to around $93 \mathrm{~km}$. At each tangent height, SCIAMACHY performed a horizontal scan with a total swath of about $960 \mathrm{~km}$. The horizontal scan is typically read out into four measurements with different azimuth angles (only one measurement in channel 1). The tangent height step between the subsequent horizontal scans is around $3.3 \mathrm{~km}$. The spatial resolution is typically $960 \mathrm{~km} \times 400 \mathrm{~km}$ in channel 1 and $240 \mathrm{~km} \times 400 \mathrm{~km}$ (across/along track) in all other channels (Gottwald and Bovensmann, 2011). The relative azimuth angle between the instrument and the sun changes in the course of the orbit. In the high northern latitudes, the instrument measurement field of view faces the solar light with a small relative azimuth angle, while in the southern latitudes the sunlight comes from behind the instrument field of view and the relative azimuth angle is large (see Figs. 4.3 and 4.4 in Ernst, 2013).

\subsection{SCIAMACHY limb V2.9 retrieval algorithm}

The current SCIAMACHY limb retrieval (V2.9) uses combined spectral information from the UV and visible spectral ranges to obtain vertical profiles of ozone (Flittner et al., 2000; Rohen et al., 2006). As the first step, the limb spectral radiances are integrated in $\pm 1 \mathrm{~nm}$ intervals around the central points. Then they are normalized with a limb measurement at an upper tangent height (often referred to as the reference tangent height): $I_{n}\left(\lambda, \mathrm{TH}_{i}\right)=I\left(\lambda, \mathrm{TH}_{i}\right) / I\left(\lambda, \mathrm{TH}_{\mathrm{ref}}\right)$, with $\lambda$ denoting wavelength and $\mathrm{TH}_{i}$ the tangent height at the elevation step $i$. The normalization removes the solar Fraunhofer structures and reduces the influence of the lower atmosphere, e.g., due to multiple scattering and reflection from the sur- 
Table 1. WOUDC and SHADOZ stations used in the validation.

\begin{tabular}{|c|c|c|c|c|c|c|c|c|c|}
\hline Station name & Height (m) & Country & Latitude & Longitude & Station name & Height (m) & Country & Latitude & Longitude \\
\hline \multicolumn{5}{|c|}{ NH high latitude } & \multicolumn{5}{|c|}{ NH midlatitude } \\
\hline Alert & 66 & CAN & $82.5^{\circ} \mathrm{N}$ & $62.3^{\circ} \mathrm{W}$ & Valentia Observatory & 14 & IRL & $51.9^{\circ} \mathrm{N}$ & $10.2^{\circ} \mathrm{W}$ \\
\hline Eureka & 10 & CAN & $80.0^{\circ} \mathrm{N}$ & $85.9^{\circ} \mathrm{W}$ & Valparaiso $^{\mathrm{a}}$ & 240 & USA & $41.5^{\circ} \mathrm{N}$ & $87^{\circ} \mathrm{W}$ \\
\hline Lerwick & 80 & GBR & $60.1^{\circ} \mathrm{N}$ & $1.2^{\circ} \mathrm{W}$ & Wallops Island & 13 & USA & $37.9^{\circ} \mathrm{N}$ & $75.4^{\circ} \mathrm{W}$ \\
\hline Ny Alesund & 11 & NOR & $78.9^{\circ} \mathrm{N}$ & $11.9^{\circ} \mathrm{E}$ & Walsingham & 200 & CAN & $42.6^{\circ} \mathrm{N}$ & $80.6^{\circ} \mathrm{W}$ \\
\hline Resolute & 46 & CAN & $74.7^{\circ} \mathrm{N}$ & $94.9^{\circ} \mathrm{W}$ & Yarmouth & 9 & CAN & $43.8^{\circ} \mathrm{N}$ & $66.1^{\circ} \mathrm{W}$ \\
\hline Sodankyla & 179 & FIN & $67.4^{\circ} \mathrm{N}$ & $26.6^{\circ} \mathrm{E}$ & \multicolumn{5}{|c|}{ Tropics } \\
\hline \multicolumn{5}{|c|}{ NH midlatitude } & Alajuela $^{b}$ & 899 & CRI & $9.9^{\circ} \mathrm{N}$ & $84.2^{\circ} \mathrm{W}$ \\
\hline Ankara & 890 & TUR & $39.9^{\circ} \mathrm{N}$ & $32.8^{\circ} \mathrm{E}$ & Ascension Island ${ }^{\mathrm{b}}$ & 79 & SHN & $7.9^{\circ} \mathrm{S}$ & $14.4^{\circ} \mathrm{W}$ \\
\hline Barajas & 631 & ESP & $40.4^{\circ} \mathrm{N}$ & $3.5^{\circ} \mathrm{W}$ & Barbados $^{\mathrm{a}} \mathrm{b}$ & 32 & BRB & $13.1^{\circ} \mathrm{N}$ & $59.4^{\circ} \mathrm{W}$ \\
\hline Bratts Lake & 580 & CAN & $50.2^{\circ} \mathrm{N}$ & $104.7^{\circ} \mathrm{W}$ & Heredia $^{b}$ & 1176 & CRI & $10^{\circ} \mathrm{N}$ & $84.1^{\circ} \mathrm{W}$ \\
\hline Churchill & 30 & CAN & $58.7^{\circ} \mathrm{N}$ & $94.1^{\circ} \mathrm{W}$ & Hilo $^{\mathrm{b}}$ & 2994 & USA & $19.4^{\circ} \mathrm{N}$ & $155.0^{\circ} \mathrm{W}$ \\
\hline DeBilt & 4 & NLD & $52.1^{\circ} \mathrm{N}$ & $5.1^{\circ} \mathrm{E}$ & Malindi $^{\mathrm{b}}$ & -6 & KEN & $3.0^{\circ} \mathrm{S}$ & $40.2^{\circ} \mathrm{E}$ \\
\hline Egbert & 251 & CAN & $44.2^{\circ} \mathrm{N}$ & $79.7^{\circ} \mathrm{W}$ & Maxaranguape (Natal) ${ }^{\mathrm{b}}$ & 14 & BRA & $5.5^{\circ} \mathrm{S}$ & $35.2^{\circ} \mathrm{W}$ \\
\hline Hohenpeissenberg & 976 & DEU & $47.8^{\circ} \mathrm{N}$ & $11^{\circ} \mathrm{E}$ & Nairobi ${ }^{b}$ & 1795 & KEN & $1.2^{\circ} \mathrm{S}$ & $36.8^{\circ} \mathrm{E}$ \\
\hline Holtville $^{\mathrm{a}}$ & -19 & USA & $32.8^{\circ} \mathrm{N}$ & $115.3^{\circ} \mathrm{W}$ & Paramaribo $^{\mathrm{b}}$ & 7 & SUR & $5.8^{\circ} \mathrm{N}$ & $55.2^{\circ} \mathrm{W}$ \\
\hline Hong Kong & 66 & HKG & $22.3^{\circ} \mathrm{N}$ & $114.1^{\circ} \mathrm{E}$ & Samoa $^{b}$ & 77 & ASM & $14.2^{\circ} \mathrm{S}$ & $170.5^{\circ} \mathrm{W}$ \\
\hline Houston & 19 & USA & $29.7^{\circ} \mathrm{N}$ & $95.4^{\circ} \mathrm{W}$ & San Cristobal ${ }^{\mathrm{b}}$ & 8 & ECU & $0.9^{\circ} \mathrm{S}$ & $89.6^{\circ} \mathrm{W}$ \\
\hline Huntsville & 196 & USA & $34.7^{\circ} \mathrm{N}$ & $86.6^{\circ} \mathrm{W}$ & San Cristobal $^{\mathrm{b}}$ & 8 & ECU & $0.9^{\circ} \mathrm{S}$ & $89.6^{\circ} \mathrm{W}$ \\
\hline Isfahan & 1550 & IRN & $32.5^{\circ} \mathrm{N}$ & $51.7^{\circ} \mathrm{E}$ & Sepang Airport ${ }^{\mathrm{b}}$ & 17 & MYS & $2.7^{\circ} \mathrm{N}$ & $101.7^{\circ} \mathrm{E}$ \\
\hline Kelowna & 456 & CAN & $49.9^{\circ} \mathrm{N}$ & $119.4^{\circ} \mathrm{W}$ & Tecamec $^{\text {b }}$ & 2272 & MEX & $19.3^{\circ} \mathrm{N}$ & $99.1^{\circ} \mathrm{W}$ \\
\hline Legionowo & 96 & POL & $52.4^{\circ} \mathrm{N}$ & $20.9^{\circ} \mathrm{E}$ & Watukosek (Java) ${ }^{\mathrm{b}}$ & 50 & IDN & $7.5^{\circ} \mathrm{S}$ & $112.6^{\circ} \mathrm{E}$ \\
\hline Naha & 28 & JPN & $26.2^{\circ} \mathrm{N}$ & $127.6^{\circ} \mathrm{E}$ & \multicolumn{5}{|c|}{ SH midlatitude } \\
\hline Narragansett & 21 & USA & $41.4^{\circ} \mathrm{N}$ & $71.4^{\circ} \mathrm{W}$ & Broadmeadows & 109 & AUS & $37.7^{\circ} \mathrm{S}$ & $144.9^{\circ} \mathrm{E}$ \\
\hline Payerne & 491 & $\mathrm{CHE}$ & $46.5^{\circ} \mathrm{N}$ & $6.5^{\circ} \mathrm{E}$ & Irene $\mathrm{e}^{\mathrm{b}}$ & 1524 & ZAF & $25.9^{\circ} \mathrm{S}$ & $28.2^{\circ} \mathrm{E}$ \\
\hline Praha & 304 & CZE & $50.0^{\circ} \mathrm{N}$ & $14.4^{\circ} \mathrm{E}$ & La Reunion Island ${ }^{\mathrm{b}}$ & 24 & REU & $21.0^{\circ} \mathrm{S}$ & $55.4^{\circ} \mathrm{E}$ \\
\hline Richland $^{\mathrm{a}}$ & 123 & USA & $46.2^{\circ} \mathrm{N}$ & $119.1^{\circ} \mathrm{W}$ & Lauder & 370 & NZL & $45.0^{\circ} \mathrm{S}$ & $169.6^{\circ} \mathrm{E}$ \\
\hline Sable Island & 4 & CAN & $43.9^{\circ} \mathrm{N}$ & $60.0^{\circ} \mathrm{W}$ & Macquarie Island & 7 & AUS & $54.5^{\circ} \mathrm{S}$ & $158.9^{\circ} \mathrm{E}$ \\
\hline Sapporo & 26 & JPN & $43.0^{\circ} \mathrm{N}$ & $141.3^{\circ} \mathrm{E}$ & Ushuaia & 17 & ARG & $54.8^{\circ} \mathrm{S}$ & $68.3^{\circ} \mathrm{W}$ \\
\hline Stonyplain & 766 & CAN & $53.5^{\circ} \mathrm{N}$ & $114.1^{\circ} \mathrm{W}$ & \multicolumn{5}{|c|}{ Antarctic } \\
\hline Table Mountain & 2285 & USA & $34.4^{\circ} \mathrm{N}$ & $117.7^{\circ} \mathrm{W}$ & Davis & 18 & ATA & $68.5^{\circ} \mathrm{S}$ & $77.9^{\circ} \mathrm{E}$ \\
\hline Trinidad Head & 20 & USA & $40.8^{\circ} \mathrm{N}$ & $124.1^{\circ} \mathrm{W}$ & Marambio & 198 & ATA & $64.2^{\circ} \mathrm{S}$ & $56.6^{\circ} \mathrm{W}$ \\
\hline Tsukuba & 31 & JPN & $36.0^{\circ} \mathrm{N}$ & $140.1^{\circ} \mathrm{E}$ & Neumayer & 38 & ATA & $70.6^{\circ} \mathrm{S}$ & $8.2^{\circ} \mathrm{W}$ \\
\hline Uccle & 100 & BEL & $50.8^{\circ} \mathrm{N}$ & $4.3^{\circ} \mathrm{E}$ & Syowa & 22 & JPN & $69.0^{\circ} \mathrm{S}$ & $39.5^{\circ} \mathrm{E}$ \\
\hline
\end{tabular}

a stations with fewer than 30 ozonesonde profiles; ${ }^{\mathrm{b}}$ stations originally from SHADOZ.

face. Furthermore, it provides a kind of self-calibration of the instrument since the instrument calibration parameters do not differ much for different tangent heights. In the visible spectral range, the so-called triplet method (Flittner et al., 2000) is used subsequently to minimize the influence of the broadband spectral features, e.g., Rayleigh and aerosol scattering. In this way the measurement vector, $\boldsymbol{y}$, is obtained from the normalized radiances at 525,589 and $675 \mathrm{~nm}$ as follows:

$$
\begin{aligned}
\boldsymbol{y}\left(\mathrm{TH}_{i}\right) & =\ln \left(I_{n}\left(589 \mathrm{~nm}, \mathrm{TH}_{i}\right)\right)-\frac{1}{2}\left[\ln \left(I_{n}\left(525 \mathrm{~nm}, \mathrm{TH}_{i}\right)\right)\right. \\
& \left.+\ln \left(I_{n}\left(675 \mathrm{~nm}, \mathrm{TH}_{i}\right)\right)\right] .
\end{aligned}
$$

Note that the central wavelength was at $600 \mathrm{~nm}$ (center of the Chappuis band) in the original triplet method. It is moved to $589 \mathrm{~nm}$ because of large calibration uncertainties near the boundary of SCIAMACHY channel 3 related to the dichroic mirror.

In the UV spectral range the method described by Rohen et al. (2006) is used. The measurement vector, $\boldsymbol{y}$, is obtained from the normalized limb radiance profiles at eight single wavelengths $(264,267.5,273,283,286,288,290.5$, and $305 \mathrm{~nm}$ ) with $\pm 1 \mathrm{~nm}$ spectral integration (Sonkaew et al., 2009). These wavelengths are chosen to avoid strong Fraunhofer lines and terrestrial airglow emissions. The SCIAMACHY limb ozone profiles are then retrieved by using a nonlinear inversion scheme with the first-order Tikhonov regularization (Rozanov et al., 2011). The relative change in the ozone concentrations with respect to a priori is retrieved. The forward modeling is done with the radiative transfer model SCIATRAN (Rozanov et al., 2014). 
In the V2.9 retrieval, the ECSTRA (Extinction Coefficient for STRatospheric Aerosol; Fussen et al., 1999) aerosol database was used in the model; the surface albedo was from Matthews (1983). The lowest and highest tangent heights used during the retrieval are around 12 and $71 \mathrm{~km}$, respectively.

\subsection{SCIAMACHY limb V3.0 retrieval algorithm}

In V3.0 retrieval approach, the extraterrestrial solar spectrum measured once per orbit by the SCIAMACHY instrument is used instead of the reference tangent height to normalize the measured limb radiances. The differential structure of the ozone absorption signature in the short-wavelength wing of the Chappuis absorption band is exploited, and the DOAS technique (differential optical absorption spectroscopy; Platt, 1994) is employed to retrieve the ozone vertical profiles instead of the highly efficient triplet method. These two changes were carried out simultaneously because

1. the short- and long-wavelength wings of the Chappuis absorption band are measured in different spectral channels of the SCIAMACHY instrument (see Sect. 2.1), and usage of the whole Chappuis band in combination with the solar spectrum normalization requires a very high quality of the inter-channel calibration;

2. the signal-to-noise ratio (SNR) decreases with increasing tangent height. Normalization using reference tangent height at high altitude will reduce the SNR at the corresponding tangent height. Because of the large SNR caused by using the whole Chappuis band, the signal is sufficient when the reference tangent height is used. However, differential structure in channel 3 suffers from very low SNR, so this influence will be much larger when used without the solar normalization.

Differential limb spectra are obtained as

$\boldsymbol{y}=\ln \left(I\left(\lambda_{L}, \mathrm{TH}_{i}\right)\right)-P_{n}$,

where $I$ is the sun-normalized radiance and $P_{n}$ is a polynomial of order $n$ (cubic in our case) in $\lambda$, whose coefficients are obtained by fitting the logarithms of the normalized limb radiance in the wavelength domain for each tangent height independently. A shift-and-squeeze correction as well as scaling factors for Ring and water vapor absorption spectra are determined at each tangent height. The shift-andsqueeze correction is done with respect to the limb-measured spectrum for both the modeled spectra and the measurement at the reference tangent height (Rozanov et al., 2005).

Since the ozone absorption signature from the shortwavelength differential absorption cross section structures of the Chappuis absorption band are weaker than the differences of the absorption between the three wavelength used in the triplet Chappuis band, the influence of weaker absorbers, namely $\mathrm{NO}_{2}$ and $\mathrm{O}_{4}$, needs to be taken into account. The weighting function of the surface albedo is also included in the fit. The aerosol extinction coefficients retrieved from SCIAMACHY limb measurements (Ernst et al., 2012) are used in the forward model. The mathematical inversion then proceeds in a manner similar to that used in the V2.9 retrieval (Rozanov et al., 2007). In the V3.0 retrieval approach, the full spectrum of the UV band (229-306) with a zero-order polynomial is used instead of the selected wavelengths as in V2.9. This however does not play any role in the comparison with the vertical profile of ozone from ozonesondes discussed in this paper as the information from the UV range does not have any significant influence on the retrieved ozone values below $30 \mathrm{~km}$ (influence above $\sim 35 \mathrm{~km}$ ). The lowest and highest tangent heights used during this retrieval are around 8 and $65 \mathrm{~km}$, respectively.

\subsection{Limb ozone data}

The IUP Bremen level 2 product provides ozone data as number densities in molecules per cubic centimeter and as volume mixing ratios in parts per million by volume (ppmv) vs. altitude within each measurement. The ECMWF operational pressure and temperature data are used to calculate the air density for converting the number density into mixing ratio.The product also contains the corresponding a priori ozone profiles as well as error estimates in both number density and volume mixing ratio representations. Cloud information is retrieved by using the SCODA (SCIAMACHY Cloud Detection Algorithm) database (Eichmann et al., 2011) and is provided as "cloud flag" in the data. In the V3.0 data product, the vertical resolution is added. The vertical resolution $S_{i}$ is calculated from the spread of the averaging kernels (Backus and Gilbert, 1970) as

$S_{i}=12 \cdot \sum_{j} A_{i j}^{2} \cdot\left(Z_{j}-Z_{i}\right)^{2} \cdot \Delta Z_{j}\left(\sum_{j} A_{i j} \cdot \Delta Z_{j}\right)^{2}$,

where $i$ represents the elevation step, $Z$ is the altitude, and $A_{i j}$ refers to the corresponding element of the averaging kernel matrix. To perform the integration, the averaging kernels need to be resampled to a finer grid. In this study 20 sublayers are used. Although the vertical resolution is not included in the V2.9 data products, in this study we calculate it in the same way as for V3.0 for the purpose of data selection (see Sect. 3.1.2). Examples of the averaging kernels, measurement response and vertical resolution resulting from both V2.9 and V3.0 are given in Fig. 1. As the retrieval is done at the measurement tangent heights, the averaging kernels for V3.0 reach a value of 1.0 at the maxima between 12 and $60 \mathrm{~km}$. For V2.9 the value is around 0.3 , which is due to the retrieval at finer grid $(1 \mathrm{~km})$ compared to the measurement grid $(\sim 3 \mathrm{~km})$. Measurement response is calculated by summing the elements of the corresponding averaging ker- 

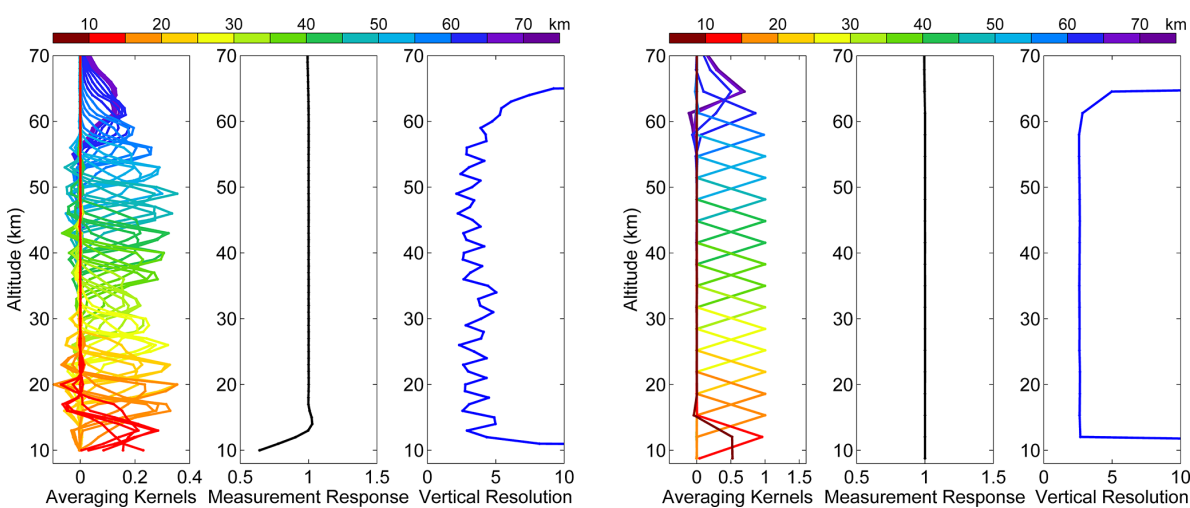

Figure 1. Averaging kernels, measurement response and vertical resolution from SCIAMACHY V2.9 (left panel) and V3.0 (right panel). Note that the $x$ axis range is different between the two panels. The example is calculated for orbit 21223; measured at 17:36 UTC on 22 March 2006; solar zenith angle of $74.95^{\circ}$; at $75.44^{\circ} \mathrm{N}$ and $93.58^{\circ} \mathrm{W}$.

nel. It describes how much information comes from the measurement. Measurement response indicates that

1. The retrieved profile is completely independent from the a priori information within the whole altitude range for V3.0 and above $12 \mathrm{~km}$ for V2.9.

2. Below $12 \mathrm{~km}, \mathrm{~V} 2.9$ may contain less information from the measurement and is more strongly affected by the a priori information compared to V3.0 (note that V3.0 uses measurement down to $8 \mathrm{~km}$, while V2.9 stops at $12 \mathrm{~km})$.

From the averaging kernels we observe the following: at the altitudes above $65 \mathrm{~km}$ profile information comes from the $60-70 \mathrm{~km}$ altitude range for both data sets; information below $12 \mathrm{~km}$ partially originates from the upper layers for both versions.

\section{Validation methodologies}

To validate the scientific ozone profiles retrieved from SCIAMACHY limb measurements, ozonesonde data from WOUDC stations are used. In order to select a reliable reference data set, only stations that have delivered more than 30 measurements between January 2003 and December 2012 are selected for the comparisons. Coincident SCIAMACHY limb profiles are selected for each ozonesonde profile. The geographic distance between the ozonesonde station and the footprint center of the collocated SCIAMACHY measurement is required to be within $5^{\circ}$ in latitude and $10^{\circ}$ in longitude. The time difference between ozonesonde and collocated SCIAMACHY measurements should not exceed $24 \mathrm{~h}$. The coincident limb profiles having a solar zenith angle larger than $80^{\circ}$ are rejected. In general, an altitude range between 15 and $30 \mathrm{~km}$ is selected for the partial-column comparison (see Sect. 3.2). This choice is motivated by larger uncertainties of the current limb retrievals below $15 \mathrm{~km}$ and increasing uncertainty in the ozonesonde data above $30 \mathrm{~km}$. The latter is mostly caused by the decaying pump efficiency at lower pressures (Johnson et al., 2002).

In the 61 ozonesonde stations that were used, 14 stations are from the tropics, 31 stations are from northern midlatitudes, 6 stations are from northern high latitudes, 6 stations are from southern midlatitudes and 4 stations are from southern high latitudes (see Table 1).

\subsection{Vertical profiles}

\subsubsection{Convolution of ozonesonde data}

Satellite data have a much coarser vertical resolution compared to the ozonesondes. To make a quantitative comparison, the ozonesonde data are degraded to the vertical resolution of the satellite data. To this end the a priori profiles and the rows of the averaging kernels from the SCIAMACHY retrieval are resampled to the vertical grid of the sonde data. The elements of the resampled a priori profiles and averaging kernel are denoted as $A_{i j}$ and $X_{\mathrm{a} j}$, respectively. The lowresolution ozonesonde profiles are obtained then as follows:

$$
\begin{gathered}
X_{\mathrm{s} i}=X_{\mathrm{a} i} \cdot\left(\sum_{j} \Delta Z_{j}\right)^{-1} \cdot \sum_{j} A_{i j} \\
\cdot \frac{X_{\mathrm{s} j}-X_{\mathrm{a} j}}{X_{\mathrm{a} j}} \cdot \Delta Z_{j}+X_{\mathrm{a} i},
\end{gathered}
$$

where $i$ represents the satellite coarse grid, and $j$ the fine grid of the ozonesonde; $\Delta Z_{j}$ is the altitude interval, i.e., a halfway distance between the layers above and below $j$.

\subsubsection{Layer selection criteria}

Two criteria were defined to screen proper vertical layers before the comparisons. Firstly, all averaging kernels used for the convolution (see Eq. 4) must not have nonzero elements above the maximum height of the corresponding ozonesonde 

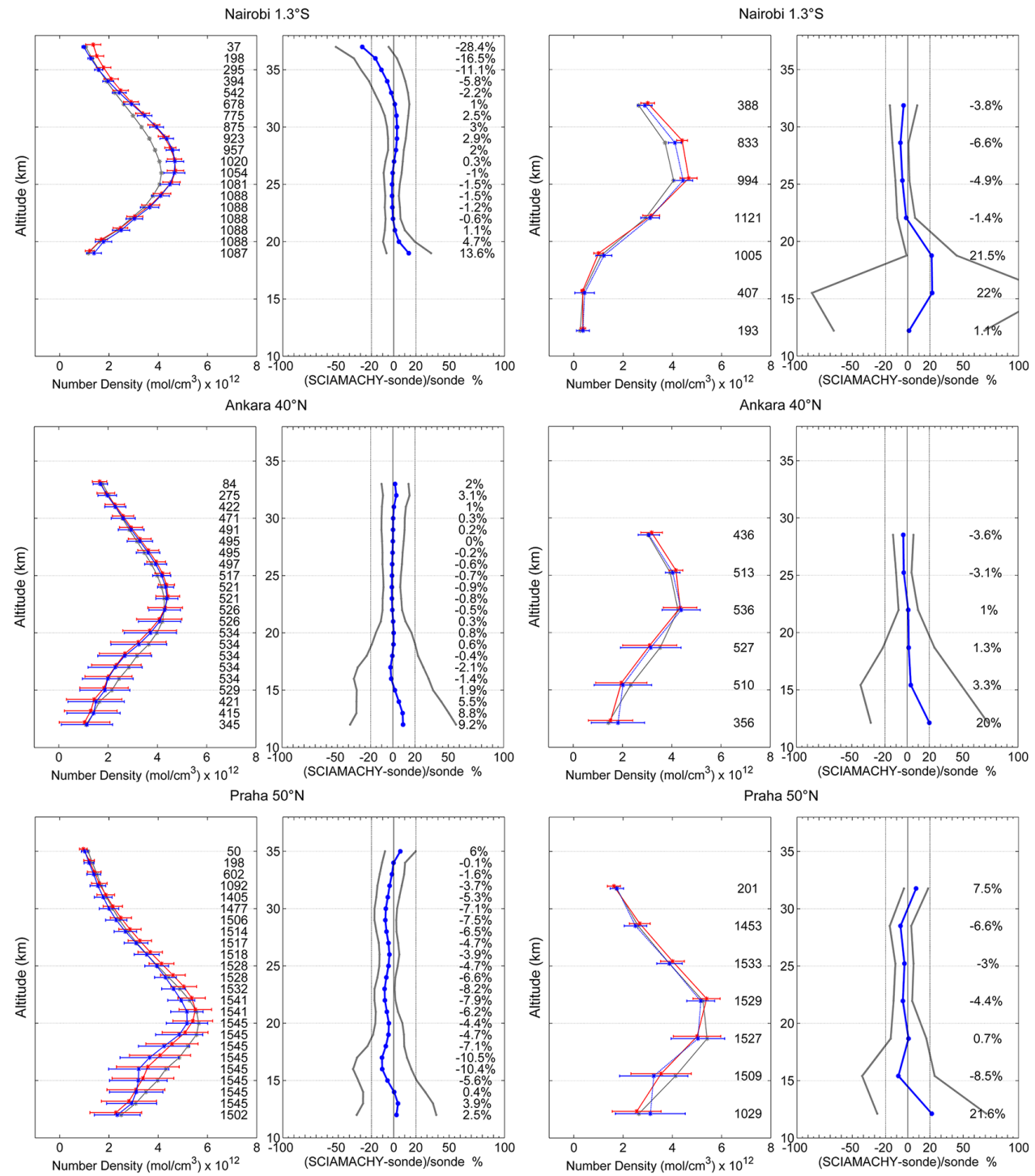

Figure 2.

measurement. Due to a coarser-altitude grid in V3.0, a wider vertical range is rejected when excluding one altitude level, which causes a different altitude range at the upper altitude in Fig. 2. Secondly, all layers below the cloud top height, as detected by the SCODA algorithm, are rejected; altitude grid points where the resulting vertical resolution is lower than $6 \mathrm{~km}$ are also not considered. Since the vertical resolution is different between the two versions, some differences in altitude range are expected.

V3.0 profiles are retrieved at the measurement grid, which varies depending on the location and time. To obtain a common altitude grid for the mean profile, all altitude levels which belong to a certain elevation step are averaged over the whole measurement time (January 2003-December 2011). Then each single profile is interpolated to the average altitude grid in each layer. At each layer the selected ozone profiles are averaged, denoted as $\overline{C_{\text {SCIA }}}$ and $\overline{C_{\text {ref }}}$. The relative mean difference at each layer is calculated as

$D=\frac{\overline{C_{\text {SCIA }}}-\overline{C_{\text {ref }}}}{\overline{C_{\text {ref }}}} \cdot 100 \%$.

The corresponding standard deviation is given by

$\operatorname{Dev}=\sqrt{\frac{1}{k-1} \sum_{i=1}^{k}(A C(i)-\overline{A C}(i))^{2}} \cdot 100 \%$,

where $k$ is the number of profiles included in the comparison and

$$
\begin{aligned}
& A C(i)=\left(C_{\mathrm{SCIA}}(i)-C_{\mathrm{ref}}(i)\right) / \overline{C_{\mathrm{ref}}} \\
& \overline{A C}(i)=D=\frac{1}{k} \sum_{i=1}^{k} A C(i) .
\end{aligned}
$$



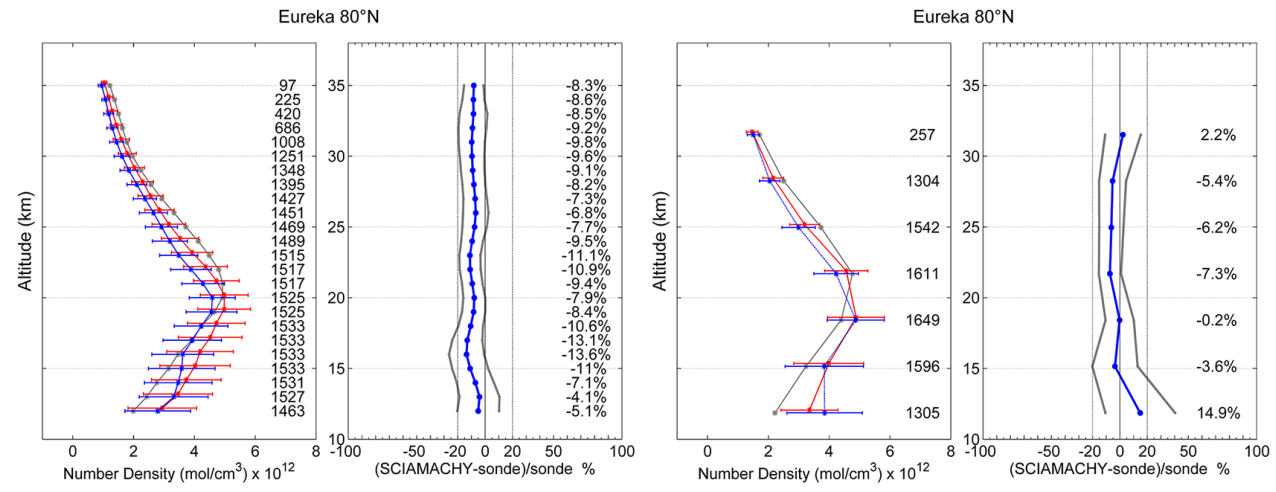

Lauder $45^{\circ} \mathrm{S}$

Lauder $45^{\circ} \mathrm{S}$
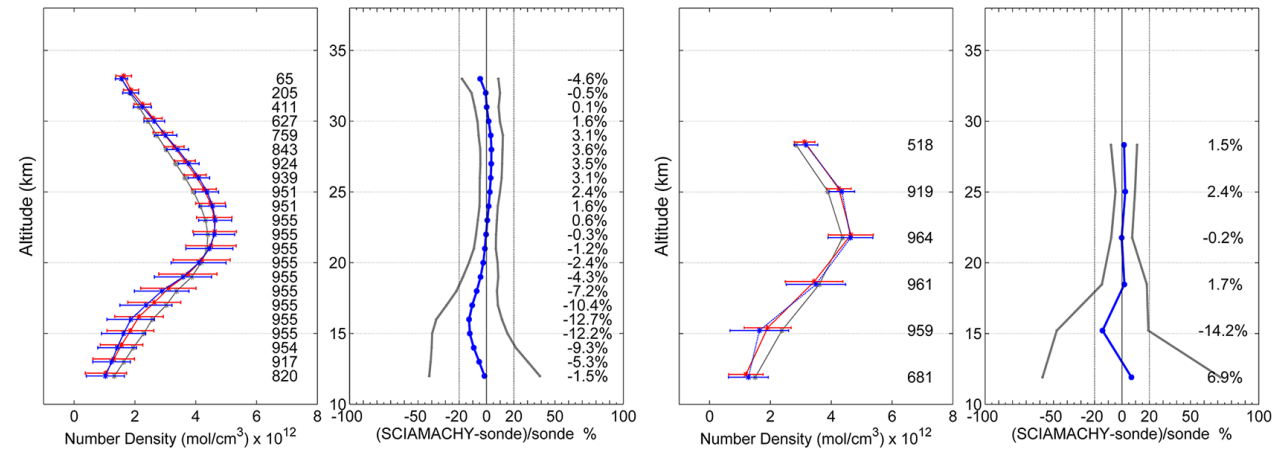

Marambio $64.2^{\circ} \mathrm{S}$
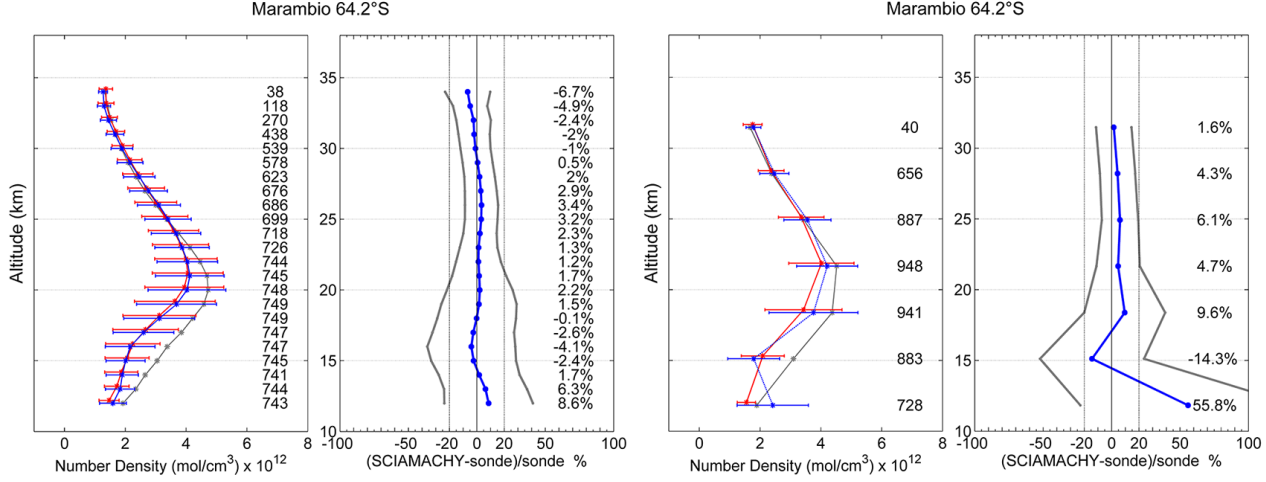

Figure 2. Vertical profile comparisons at Nairobi $\left(1.2^{\circ} \mathrm{N}, 36.8^{\circ} \mathrm{E}\right)$, Ankara $\left(40.0^{\circ} \mathrm{N}, 32.8^{\circ} \mathrm{E}\right)$, Praha $\left(50.0^{\circ} \mathrm{N}, 14.4^{\circ} \mathrm{E}\right)$, Eureka $\left(80.0^{\circ} \mathrm{N}\right.$, $\left.85.9^{\circ} \mathrm{W}\right)$, Lauder $\left(44.9^{\circ} \mathrm{S}, 169.7^{\circ} \mathrm{E}\right)$ and Marambio $\left(64.2^{\circ} \mathrm{S}, 56.6^{\circ} \mathrm{W}\right)$ averaged from January 2003 to December 2012 . The four panels show the results for the ozone profiles for V2.9 on the left-hand side and for V3.0 on the right-hand side. In the left subpanels, the red and blue curves represent the ozone number densities with $1 \sigma$ standard deviations for ozonesonde and SCIAMACHY limb data, respectively. The gray lines show a priori information used in the SCIAMACHY retrieval. In the right subpanels, the blue lines represent the relative mean differences of the ozone concentrations. The gray solid lines depict $1 \sigma$ standard deviations. The numbers on the right denote the number of SCIAMACHY limb profiles used in the comparisons and the relative differences for each layer.

\subsection{Partial-column comparisons}

In addition to the vertical profile comparison, both SCIAMACHY limb ozone data and original ozonesonde measurements are integrated and compared as the stratospheric partial ozone columns (hereafter SC). For each individual pair of SCIAMACHY-sonde profiles, the integration is started either from the first cloud-free level of SCIAMACHY limb data or from $15 \mathrm{~km}$, whichever is higher, and ended at either the ozonesonde explosion position or at $30 \mathrm{~km}$, whichever is lower.

$$
C_{\text {strato }}=\sum_{i_{\mathrm{tph}}}^{i=\mathrm{TH}_{\max }}\left(\frac{N\left(Z_{i-1}\right)+N\left(Z_{i}\right)}{2}\right)\left(Z_{i}-Z_{i-1}\right),
$$

where $C_{\text {strato }}$ refers to a individual $\mathrm{SC}, N(z)$ is the stratospheric ozone profile in number density units $\left(\mathrm{mol} \mathrm{cm}^{-3}\right), z_{i}$ represents the altitude in kilometers and $i$ is the layer index. 


\section{Results and discussion}

\subsection{Vertical profile comparison results for V2.9 and V3.0}

Average vertical profiles from the coincident SCIAMACHY and ozonesonde measurements at the six selected stations for the period January 2003-December 2011 are compared in Fig. 2. The stations Nairobi, Ankara, Praha, Eureka, Lauder and Marambio are chosen as representatives of the latitude bins $20^{\circ} \mathrm{S}-20^{\circ} \mathrm{N}, 20-40^{\circ} \mathrm{N}, 40-60^{\circ} \mathrm{N}, 60-90^{\circ} \mathrm{N}, 20-60^{\circ} \mathrm{S}$ and $60-90^{\circ} \mathrm{S}$, respectively. The panels represent the results of V2.9 on the left-hand side and of V3.0 on the right-hand side. For each station, the vertical comparisons are shown as vertical profiles (left panels) and relative mean differences (right panels). The number densities for both sonde and SCIAMACHY limb data at each layer are obtained by averaging the filtered data (see Sect. 3.1.2) over the entire time period. At Nairobi, V2.9 agrees with ozonesonde results to within $3 \%$ for most cases below $30 \mathrm{~km}$. There are good agreements at Ankara, Lauder and Marambio with usually less than $5 \%$ relative differences. The differences become larger at Lauder below $18 \mathrm{~km}$. A negative bias shows up at Praha and becomes stronger at Eureka, which has a higher latitude (Fig. 2). Furthermore, the relative differences at these latitudes exhibit vertical oscillations of about $3 \%$ amplitude. The maxima of the relative differences are seen at around 22 and $28 \mathrm{~km}$. The oscillations are most probably caused by the fact that the radiance profiles, sampled by the SCIAMACHY instrument at different tangent heights, are not exactly aligned vertically (Brinksma et al., 2006). At these latitudes, the horizontal variations of the stratospheric ozone are usually stronger as compared to other latitudes, and thus the oscillations are more pronounced.

To give a global overview of the results, the altitudeversus-latitude cross sections of the relative differences for both versions are given in Fig. 3. They are calculated by contouring the relative mean differences between SCIAMACHY limb data and correlative sonde data at all considered sonde stations (61 stations in total). In general, the current V2.9 data well reproduce the ozone vertical distribution by following the shapes of ozonesonde data at each station (upper panel of Fig. 3). The relative differences between V2.9 and ozonesonde data are within $5 \%$ between 20 and $30 \mathrm{~km}$ southward of $40^{\circ} \mathrm{N}$. The good agreement seen at Nairobi holds for most of the cases in the tropical region. One exception is seen around the ozone peak altitude $(\sim 26 \mathrm{~km})$ in the near-equatorial northern tropics. This overestimation can be clearly observed (see upper panel of Fig. 3) at Sepang Airport (Kuala Lumpur) and Hong Kong stations, with more than $10 \%$ relative differences in the upper stratosphere (25$30 \mathrm{~km}$ ). In the middle and high southern latitudes, V2.9 still represents the ozone vertical distribution very well by agreeing with ozonesonde data to within $5 \%$, which is consistent with the results of station Ankara, Lauder and Marambio in
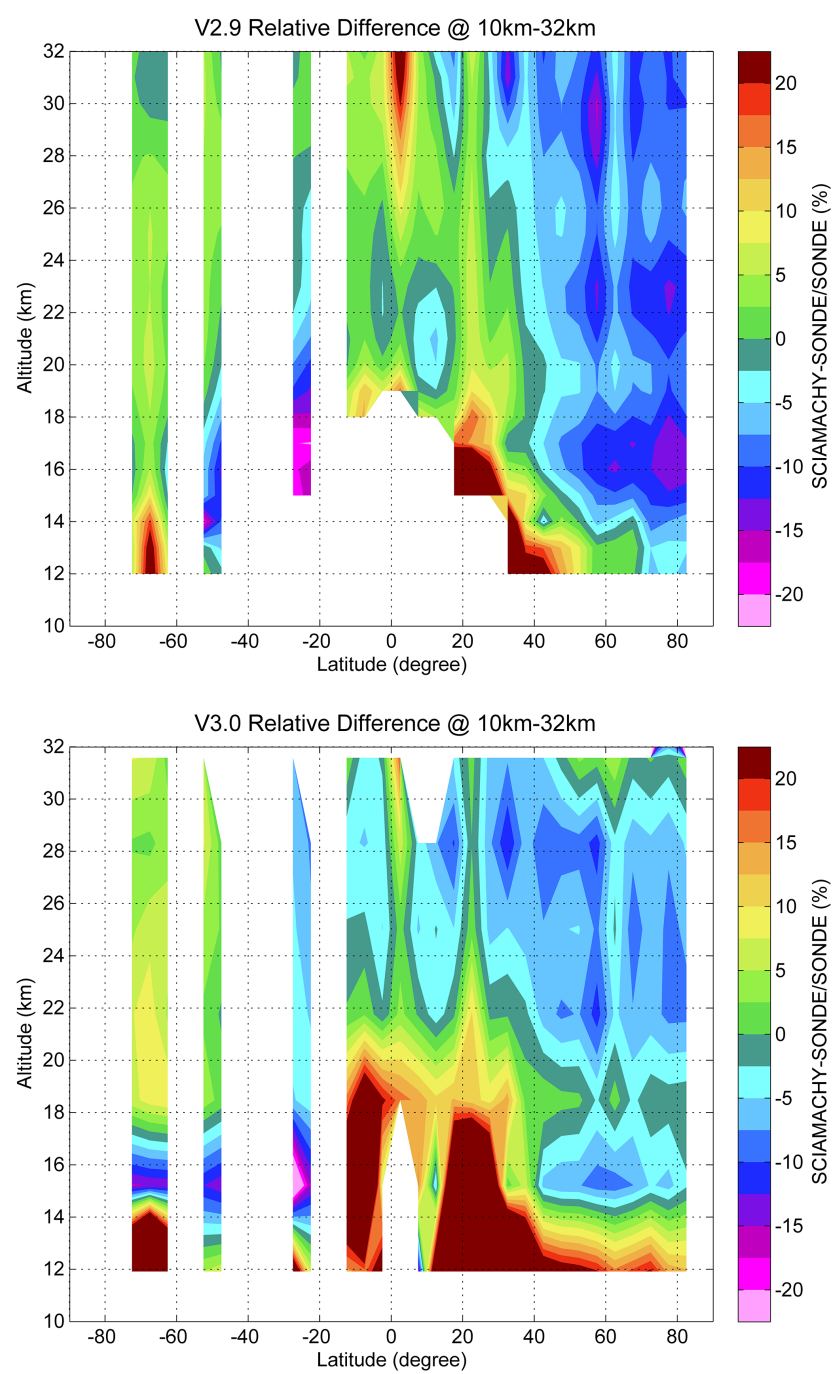

Figure 3. The altitude-versus-latitude cross section of the relative differences. V2.9 in the upper panel and V3.0 in the lower panel. The improvement is mainly in the NH high latitudes.

Fig. 2. In the Northern Hemisphere, this consistent agreement degrades northward of $\sim 40^{\circ} \mathrm{N}$, showing stronger underestimation with increasing latitude up to $\sim 15 \%$. The oscillations we see in Praha and Eureka in Fig. 2 can be observed, too.

The vertical profile comparison results from upcoming V3.0 data sets are presented in the lower panel of Fig. 3 in the same way as for V2.9. In comparison to the current V2.9 data sets, V3.0 shows similar retrieval quality in most of the cases, with the exception of a slightly worse agreement at Nairobi (shown in the panel of Fig. 2), while the overestimations over Southeast Asia (e.g., Kuala Lumpur, Hong Kong) in V2.9 are revised (Fig. 3). It is seen clearly that the ozone concentrations at middle and high northern latitudes, e.g., Praha and Eureka, are captured more accurately in V3.0 than in V2.9. For example, at Eureka the relative differences 
are reduced from $\sim 13$ to within $7.5 \%$. The vertical oscillations can still be observed but are much weaker. V3.0 agrees with ozonesonde within $10 \%$ globally, with a significant improvement northwards of $40^{\circ} \mathrm{N}$ (Fig. 3). One exception remains below $18 \mathrm{~km}$ at southern high latitudes, where the relative differences vary strongly. The reasons for this issue are still under investigation.

Figures 4 and 5 show annual and seasonal relative differences for V2.9, respectively. The relative mean differences at all tropical (not shown in the paper) and midlatitude stations do not have much dependence on the year of measurements. However, the relative differences drift from year to year at high latitudes of both hemispheres (see Fig. 4). The statistics of the seasonal behavior is presented in Fig. 5. No obvious seasonal influence can be identified in this comparison. Since V3.0 has similar seasonal and yearly behavior (apart from the reduced bias at Eureka and Praha) of the vertical profiles to that of V2.9, the results are not shown.

\subsection{Partial-column comparison results for $\mathrm{V} 2.9$ and V3.0}

Apart from vertical information, the limb partial columns are used for tropospheric ozone retrieval using the residual method (Ebojie et al., 2014). Therefore, in addition to the vertical profile comparison, the results of partial-column comparisons are presented in Figs. 6-8. Figure 6 depicts the time series of ozonesonde data sets (red dots), SCIAMACHY data sets (green dots) and their differences (blue dots) at Nairobi and Eureka. The ozone amounts are represented as daily averaged SCs in DU. The left panels represent the current V2.9, while the right ones represents the upcoming V3.0. Figures 7-8 show the statistical results for the differences of SCs in DU between the ozonesonde and the SCIAMACHY data on a global scale. Figure 7 shows the global overview of the absolute and relative averaged daily differences, while Fig. 8 presents scatterplots of the absolute differences for latitude bins. Note that the absolute differences in Fig. 7 are calculated as the averages of the daily mean SCs differences, while in Fig. 8 each dot represents the absolute difference for a single collocation.

Similar conclusions to those for the vertical profile comparisons can be drawn from the partial-column comparisons. For the V2.9 data set, the seasonal variations in the time series agree well with those from sonde data (left panels of Fig. 6). The drift of relative differences with time that is mentioned in Sect. 4.1 can be observed also in Fig. 6 at Eureka. So far there is no explanation about this drift. The agreement of daily mean differences is mostly within 5 DU southwards from $40^{\circ} \mathrm{N}$. The overestimation in Southeast Asia observed in Fig. 3 corresponds to $\sim 10 \mathrm{DU}$ absolute differences as shown in Fig. 7. A general overestimation in the Pacific Ocean can also be observed. In the northern middle and high latitudes, a rapid decrease in the quality of the V2.9 ozone data results in, e.g., a median difference of $22 \mathrm{DU}$ (over 10\%) at Eureka. The underestimations are depicted by the purple and pink dots in Fig. 7 and amount to about $\sim 13 \mathrm{DU}$ in Europe and Canada and more than $20 \mathrm{DU}$ in the high northern latitudes.

For V3.0, the seasonal variations in the time series are in good agreement with those from sonde data; at Eureka a median difference in partial columns decreases by $16 \mathrm{DU}$ to only 6DU (right panel of Fig. 6). The improvement northwards of $40^{\circ} \mathrm{N}$ changes the color in Fig. 7 from purple-pink to blue. V3.0 also improved the partial-column accuracy at most tropical stations (10 out of 12 stations with abundant measurements) with a remarkable $\sim 5 \%$ improvement from more than 8 to within $4 \%$ over the tropical Pacific region.

A global improvement can be observed in the statistical results for different latitude bins (Fig. 8), illustrating better retrieval results for each single measurement. A striking improvement is seen in the high-latitude bin $\left(60-90^{\circ} \mathrm{N}\right)$. With an improved linear slope of 0.94 vs. 0.85 and smaller standard deviation of $\sigma=7.4 \mathrm{DU}$ vs. $13.7 \mathrm{DU}$, the V3.0 data set exhibits a much better agreement with ozonesonde data at northern high latitudes. At the same time, the correlations at other latitude bins also become higher in varying degrees. A very strong improvement can be observed also in southern midlatitudes (Fig. 8). Due to the relatively low and centered ozone partial column, a smaller correlation is obtained in the tropics for both versions.

\subsection{Discussions}

The reasons for the underestimation found in V2.9 data at higher latitudes can be identified by analyzing the left panel of Fig. 9. The figure shows a comparison of ozone vertical profiles from SCIAMACHY V2.9 data (blue solid line) and from ozonesonde (black solid line) at Eureka for 22 March 2006. A clear underestimation of the peak value near $17 \mathrm{~km}$ is observed in V2.9 data. This is a typical behavior that explains the underestimation described above. As this artifact could not be reproduced in the synthetic retrievals, which include a full range of forward model parameters, it is most probably caused by instrumental issues. One possible explanation is a presence of an increased external stray light when performing limb measurements at large solar zenith angles and small azimuth angles. In this geometry, which is typical for SCIAMACHY observations at high northern latitudes, the extraterrestrial solar radiance is believed to be reflected by some part of Envisat into the field of view of the SCIAMACHY instrument.

The retrieval methodology used in the new V3.0 aims to reduce the underestimations in the northern high latitudes shown by V2.9. In the V3.0 retrieval processor, signals from different wavelengths are exploited (Sect. 2.3). The spectral window used in the visible region is narrower compared to V2.9. On the one hand it uses weaker absorption features of ozone, thus gaining less information from the spectra. On the other hand, by using the narrow spectral window and higher 

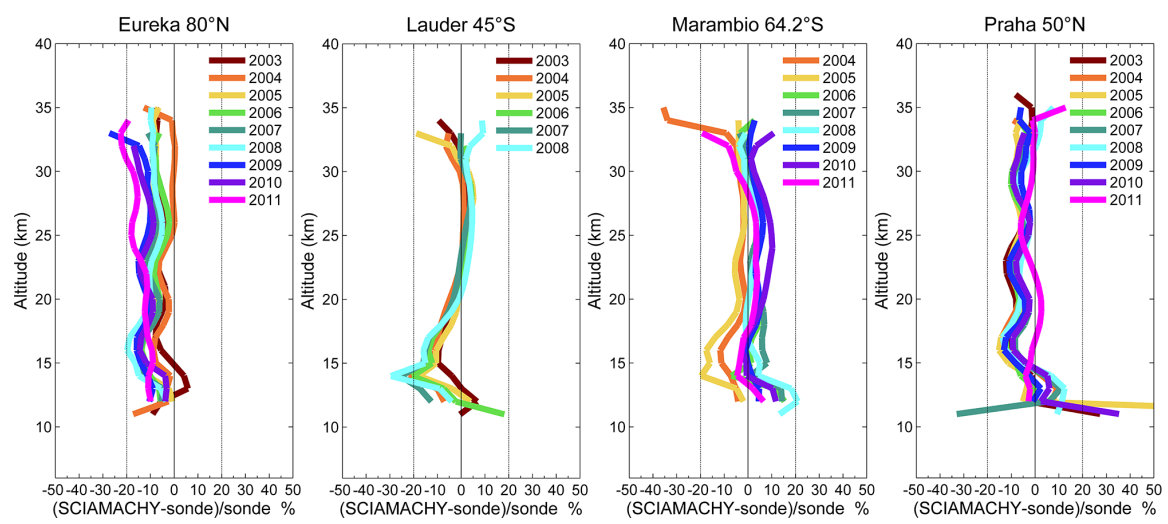

Figure 4. V2.9 yearly vertical profile comparisons of the relative differences between SCIAMACHY and ozonesondes at Eureka, Lauder, Marambio and Praha.
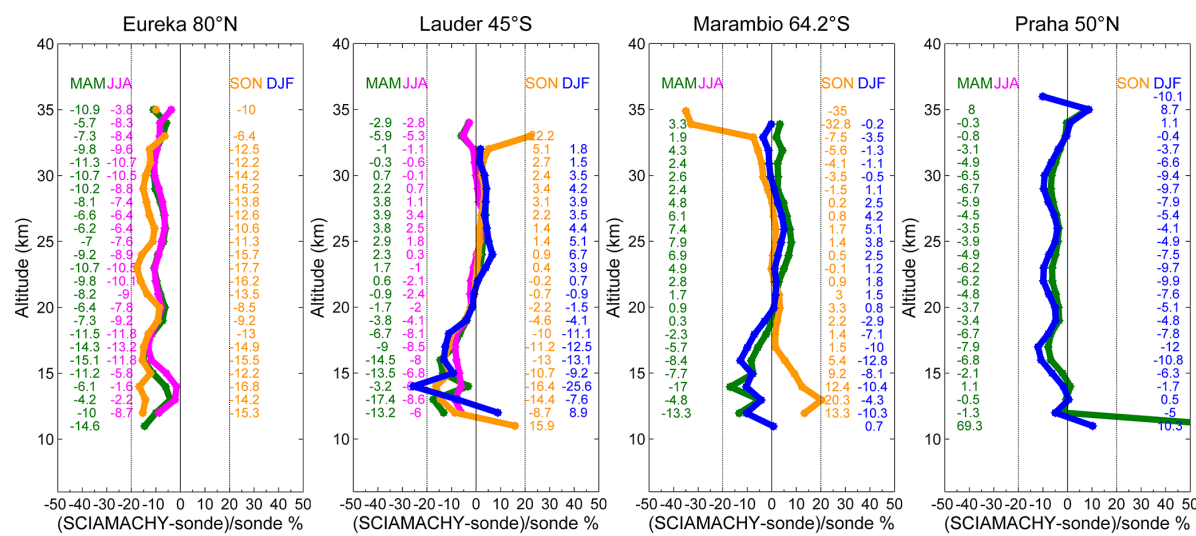

Figure 5. V2.9 seasonal vertical profile comparisons of the relative differences between SCIAMACHY and ozonesondes from 2003 to 2011 at Eureka, Lauder, Marambio and Praha. No/not enough corresponding measurements in DJF for Eureka, in JJA for Marambio, and in JJA and SON for Praha.

order of the closure polynomial the influence of the systematic errors is reduced. The right panel of Fig. 9 shows the comparison of ozone vertical profiles from SCIAMACHY limb V3.0 data with ozonesonde data presented in the same way as V2.9 results in the left panel. It is seen clearly that the ozone maximum at $17 \mathrm{~km}$ observed by the sonde is now captured properly by SCIAMACHY. Furthermore, the V3.0 data set also better reproduces the ozone maximum around $25 \mathrm{~km}$ in the tropics (not shown here), which corrects the overestimation in Southeast Asia as seen from both vertical and partial-column comparisons. General improvement in the Pacific and the South Atlantic Ocean regions can be observed in the partial-column comparisons (Fig. 7). This may be partly due to the opposite sign of differences at different altitude. As shown in the sections above, the new V3.0 is a success in solving the underestimation of northern high latitudes.

\section{Conclusions}

SCIAMACHY limb ozone scientific data sets, namely the current V2.9 and the new V3.0, were extensively compared with ozonesonde measurements for the time period of 2003 2011, from 61 sonde stations. The two versions of SCIAMACHY limb data use different retrieval processors. The main differences are that in visible spectral region V2.9 uses a reference tangent height and the triplet method, while V3.0 employs a solar spectrum as the reference and performs a DOAS type fit. There are also some changes in the UV band (Sects. 2.2 and 2.3); these however do not provide information at altitudes less than $30 \mathrm{~km}$.

V2.9 agrees well with the ground-based data within a latitude range of $90^{\circ} \mathrm{S}-40^{\circ} \mathrm{N}$. The relative differences between the two databases are within 5\% (SCIAMACHY is mostly overestimating) at $20-30 \mathrm{~km}$. It shows very good retrieval results in the tropics, with a difference of less than $3 \%$ vertically. The partial-column comparisons show less than $5 \mathrm{DU}$ absolute differences with rather small standard deviation, with the exception of the tropical Pacific region, where an 

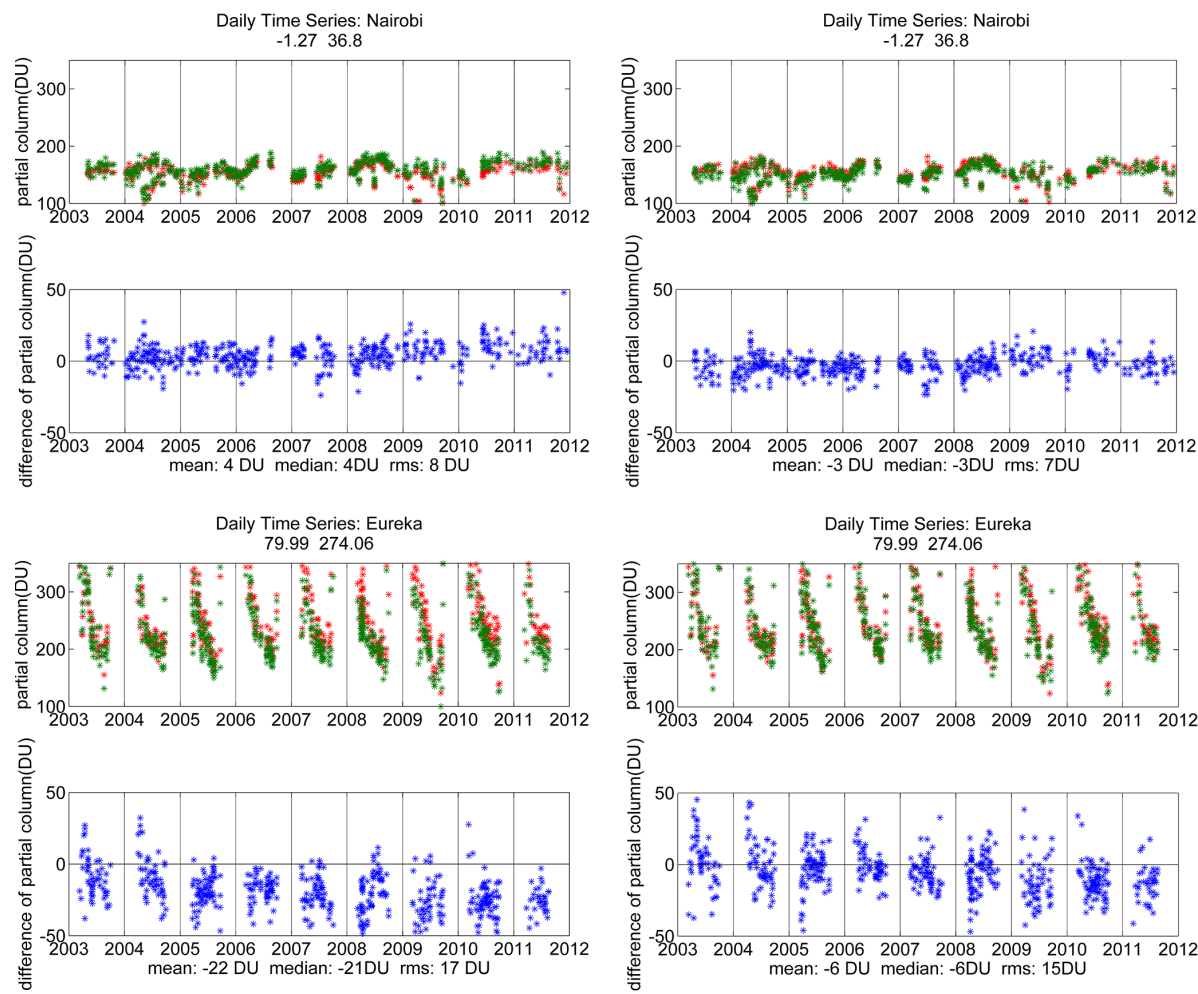

Figure 6. Time series of stratospheric ozone partial columns from SCIAMACHY V2.9 and V3.0 (left and right panels, respectively) limb data (green), ozonesonde data (red) (upper panel) and their absolute difference in SCs (blue) in DU. The results are presented unsmoothed.
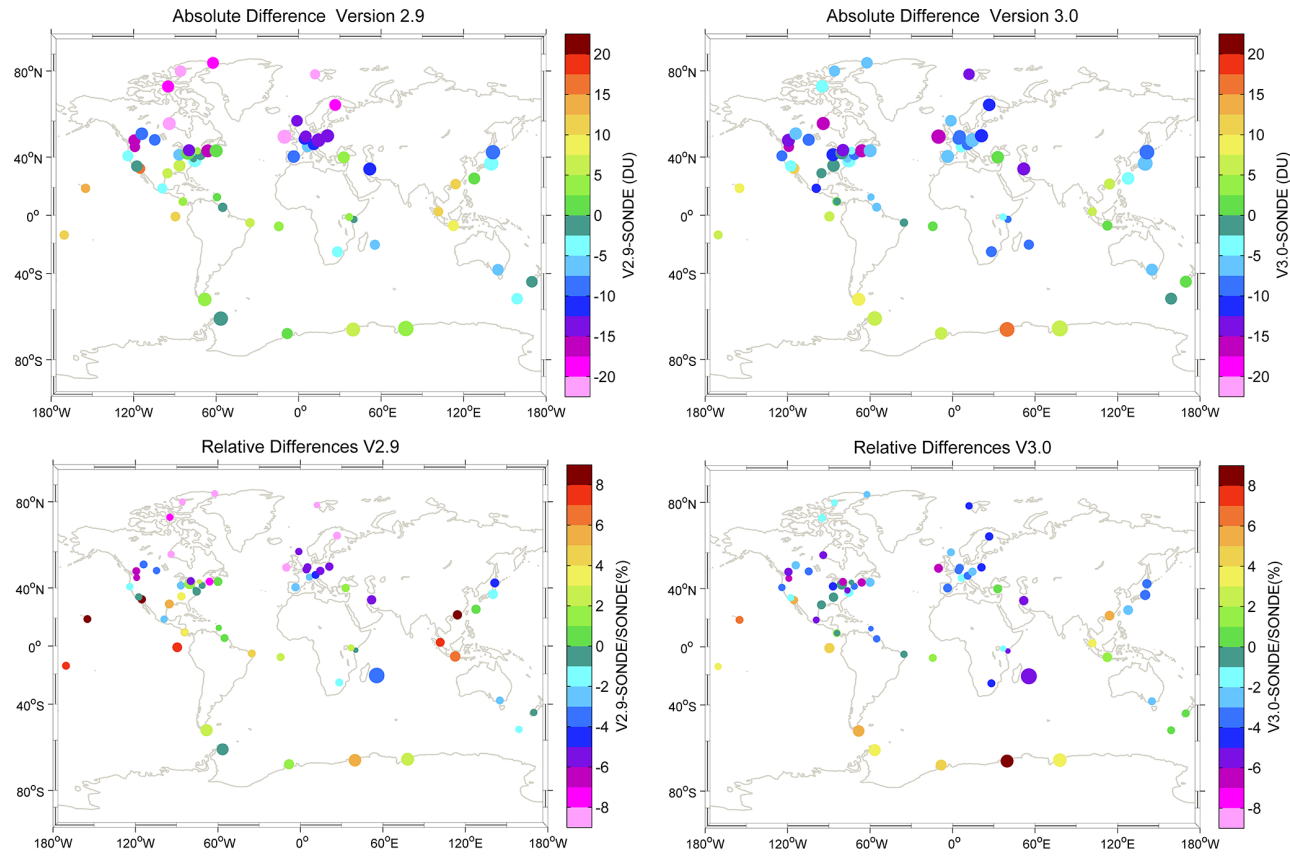

Figure 7. Comparison with all considered ozonesonde station data for the averaged daily differences in partial columns over the entire time period. The upper panels are the absolute differences; the lower panels are the relative differences. In each panel, the color of the dots depicts the mean difference/relative mean difference, while the size of the dots represents $1 \sigma$ standard deviation. 

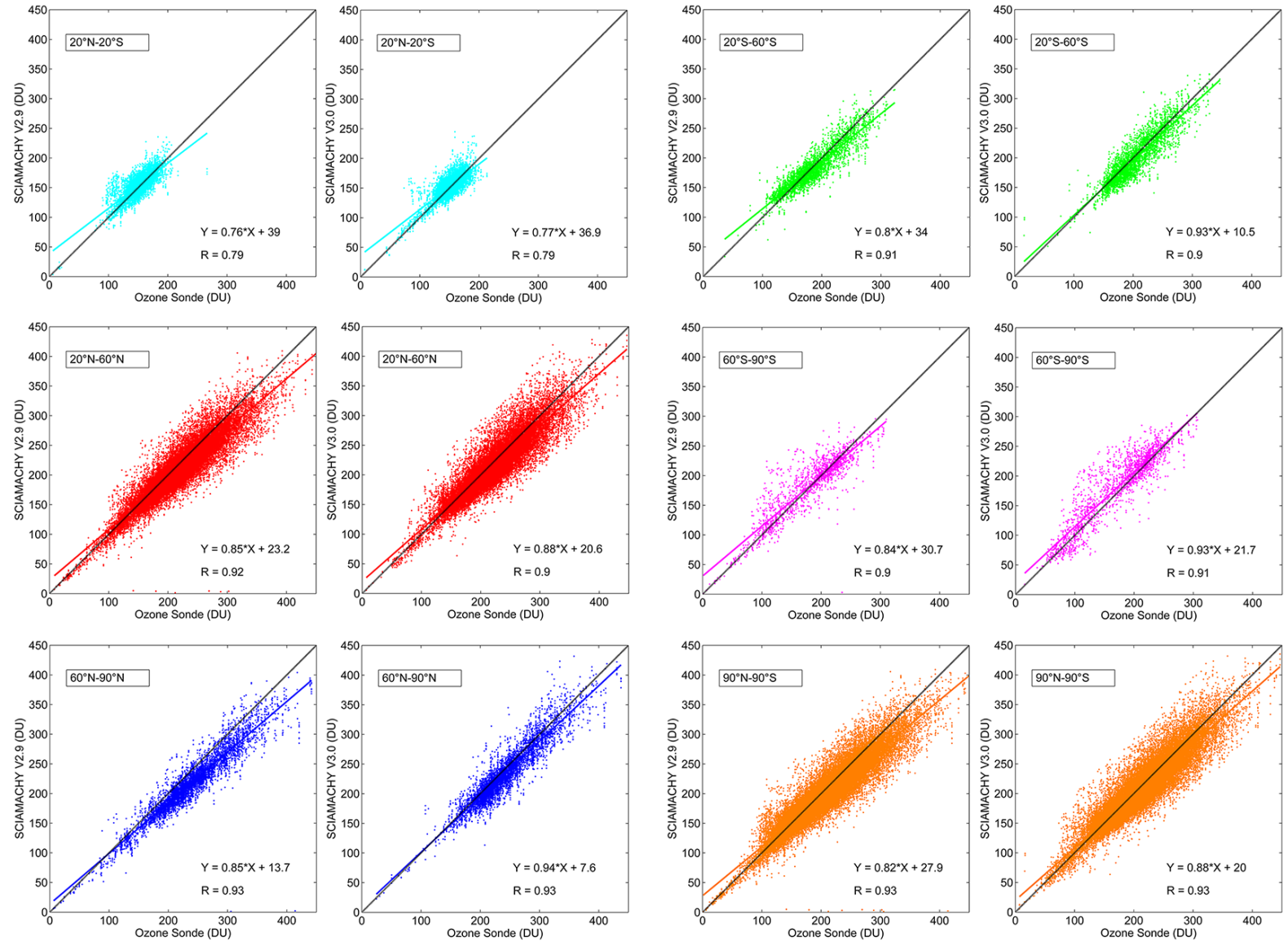

Figure 8. Scatterplots of the partial columns from SCIAMACHY and ozonesonde data within $20^{\circ} \mathrm{S}-20^{\circ} \mathrm{N}, 20-60^{\circ} \mathrm{N}, 60-90^{\circ} \mathrm{N}, 20-60^{\circ} \mathrm{S}$, $60-90^{\circ} \mathrm{S}$ and $90^{\circ} \mathrm{S}-90^{\circ} \mathrm{N}$ latitude bins. Left panels from V2.9; right panels from V3.0.
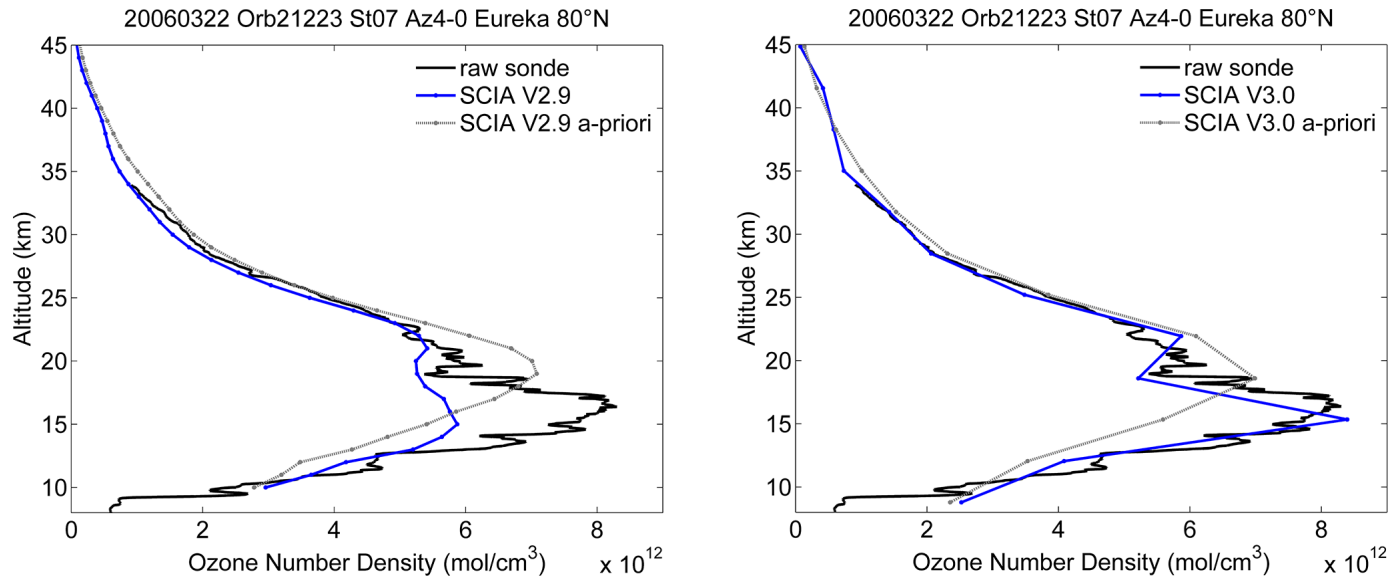

Figure 9. Comparison of ozone vertical profiles from SCIAMACHY and from ozonesonde at the Eureka station.

overestimation of more than $10 \%$ is observed. These overestimations result from a significant positive bias above $25 \mathrm{~km}$ (so far there is no explanation for the reason behind this bias). In the northern high latitudes V2.9 shows an up to $\sim 15 \%$ negative bias with observable vertical oscillations, which is believed to be the consequences of the increased external stray light. The ozone partial columns are underestimated by 12-20 DU.

The new V3.0 has been developed to reduce the underestimation in the northern high latitude identified in V2.9. As 
a result the differences are reduced to within $10 \%$ for vertical profiles and 5-10 DU for partial columns northward of $40^{\circ} \mathrm{N}$. At the same time, the overestimation of the ozone profile concentrations around the tropical Pacific are eliminated. We show that V3.0 maintains the good retrieval results also southwards of $40^{\circ} \mathrm{N}$, with deviations slightly larger than $5 \%$ in the tropics and within $10 \%$ in the southern high latitude.

The Huggins band is believed to improve ozone retrieval accuracy between 30 and $45 \mathrm{~km}$ and will be included in V3.1 limb ozone retrieval.

Acknowledgements. We acknowledge WOUDC (http://woudc.org) for providing ozonesonde data sets. We acknowledge the GALAHAD Fortran library used for V3.0 retrieval (Gould et al., 2003). J. Jia acknowledges funding by CSC (China Scholarship Council). We also acknowledge financial support provided by ESSReS (Earth System Science Research School) and the BMBF ROMIC project. This work has also been funded in parts by the German Aerospace DLR project SADOS (FKZ 50EE1105) and by the University of Bremen as well as the federal state of Bremen. We thank our colleagues for continued support and discussion.

The article processing charges for this open-access publication were covered by the University of Bremen.

Edited by: F. Khosrawi

\section{References}

Backus, G. E. and Gilbert, F. E.: Uniqueness in the inversion of inaccurate gross Earth data, Philos. T. Roy. Soc. A, 266, 1173, 123-192, 1970.

Bertaux, J. L., Kyrölä, E., Fussen, D., Hauchecorne, A., Dalaudier, F., Sofieva, V., Tamminen, J., Vanhellemont, F., Fanton d'Andon, O., Barrot, G., Mangin, A., Blanot, L., Lebrun, J. C., Pérot, K., Fehr, T., Saavedra, L., Leppelmeier, G. W., and Fraisse, R.: Global ozone monitoring by occultation of stars: an overview of GOMOS measurements on ENVISAT, Atmos. Chem. Phys., 10, 12091-12148, doi:10.5194/acp-10-12091-2010, 2010.

Bovensmann, H., Burrows, J. P., Buchwitz, M., Frerick, J., Noël, S., Rozanov, V. V., Chance, K. V., and Goede, A. P. H.: SCIAMACHY: mission objectives and measurement modes, J. Atmos. Sci., 56, 127-150, 1999

Brinksma, E. J., Bracher, A., Lolkema, D. E., Segers, A. J., Boyd, I. S., Bramstedt, K., Claude, H., Godin-Beekmann, S., Hansen, G., Kopp, G., Leblanc, T., McDermid, I. S., Meijer, Y. J., Nakane, H., Parrish, A., von Savigny, C., Stebel, K., Swart, D. P. J., Taha, G., and Piters, A. J. M.: Geophysical validation of SCIAMACHY Limb Ozone Profiles, Atmos. Chem. Phys., 6, 197-209, doi:10.5194/acp-6-197-2006, 2006.

Burrows, J., Hölzle, E., Goede, A., Visser, H., and Fricke, W.: SCIAMACHY - scanning imaging absorption spectrometer for atmospheric chartography, Acta Astronaut., 35, 445-451, 1995.

Burrows, J. P., Weber, M., Buchwitz, M., Rozanov, V. V., LadstätterWeißenmayer, A., Richter, A., de Beek, R., Hoogen, R., Bramstedt, K., Eichmann, K.-U., Eisinger, M., and Perner, D.: The
Global Ozone Monitoring Experiment (GOME): Mission Concept and First Scientific Results, J. Atmos. Sci., 56, 151-175, 1999.

Callies, J., Corpaccioli, E., Eisinger, M., Hahne, A., and Lefebvre, A.: GOME-2 metops second-generation sensor for operational ozone monitoring, ESA Bulletin, 102, 28-36, 2000.

Clerbaux, C., Boynard, A., Clarisse, L., George, M., Hadji-Lazaro, J., Herbin, H., Hurtmans, D., Pommier, M., Razavi, A., Turquety, S., Wespes, C., and Coheur, P.-F.: Monitoring of atmospheric composition using the thermal infrared IASI/MetOp sounder, Atmos. Chem. Phys., 9, 6041-6054, doi:10.5194/acp-9-6041-2009, 2009.

Eichmann, K.-U., von Savigny, C., Weigel, K., Reichl, P., Robert, C., Steinwagner, J., Bovensmann, H., and Burrows, J. P.: SCODA V1.9: SCIAMACHY Cloud Detection Algorithm from Limb Radiance Measurements, Algorithm Theoretical Baseline Document (ATBD), University of Bremen, Bremen, Germany, 2011.

Ebojie, F., von Savigny, C., Ladstätter-Weißenmayer, A., Rozanov, A., Weber, M., Eichmann, K.-U., Bötel, S., Rahpoe, N., Bovensmann, H., and Burrows, J. P.: Tropospheric column amount of ozone retrieved from SCIAMACHY limb-nadir-matching observations, Atmos. Meas. Tech., 7, 2073-2096, doi:10.5194/amt-72073-2014, 2014.

Ernst, F.: Stratospheric aerosol extinction profile retrievals from SCIAMACHY limb-scatter observations, $\mathrm{PhD}$ thesis, University of Bremen, Bremen, Germany, 2013.

Ernst, F., von Savigny, C., Rozanov, A., Rozanov, V., Eichmann, K.-U., Brinkhoff, L. A., Bovensmann, H., and Burrows, J. P.: Global stratospheric aerosol extinction profile retrievals from SCIAMACHY limb-scatter observations, Atmos. Meas. Tech Discuss., 5, 5993-6035, doi:10.5194/amtd-5-5993-2012, 2012.

Fischer, H., Birk, M., Blom, C., Carli, B., Carlotti, M., von Clarmann, T., Delbouille, L., Dudhia, A., Ehhalt, D., Endemann, M., Flaud, J. M., Gessner, R., Kleinert, A., Koopman, R., Langen, J., López-Puertas, M., Mosner, P., Nett, H., Oelhaf, H., Perron, G., Remedios, J., Ridolfi, M., Stiller, G., and Zander, R.: MIPAS: an instrument for atmospheric and climate research, Atmos. Chem. Phys., 8, 2151-2188, doi:10.5194/acp-8-2151-2008, 2008.

Flittner, D. E., Bhartia, P. K., and Herman, B. M.: $\mathrm{O}_{3}$ profiles retrieved from limb scatter measurements: theory, Geophys. Res. Lett., 27, 2601-2604, 2000.

Fussen, D. and Bingen, C.: A volcanism dependent model for the extinction profile of stratospheric aerosols in the UV-visible range, Geophys. Res. Lett., 26, 703-706, 1999.

Gould, N. I. M., Orban, D., and Toint, P. L.: GALAHAD, a library of thread-safe Fortran 90 packages for large-scale nonlinear optimization, ACM T. Math. Software, 29, 353-372, 2003.

Gottwald, M. and Bovensmann, H. (Eds.): SCIAMACHY - Exploring the Changing Earth's Atmosphere, Springer, Dordrecht, the Netherlands, 2011.

Hassler, B., Petropavlovskikh, I., Staehelin, J., August, T., Bhartia, P. K., Clerbaux, C., Degenstein, D., Mazière, M. De, Dinelli, B M., Dudhia, A., Dufour, G., Frith, S. M., Froidevaux, L., GodinBeekmann, S., Granville, J., Harris, N. R. P., Hoppel, K., Hubert, D., Kasai, Y., Kurylo, M. J., Kyrölä, E., Lambert, J.-C., Levelt, P. F., McElroy, C. T., McPeters, R. D., Munro, R., Nakajima, H., Parrish, A., Raspollini, P., Remsberg, E. E., Rosenlof, K. H., Rozanov, A., Sano, T., Sasano, Y., Shiotani, M., Smit, H. G. J., 
Stiller, G., Tamminen, J., Tarasick, D. W., Urban, J., van der A, R. J., Veefkind, J. P., Vigouroux, C., von Clarmann, T., von Savigny, C., Walker, K. A., Weber, M., Wild, J., and Zawodny, J. M.: Past changes in the vertical distribution of ozone -Part 1: Measurement techniques, uncertainties and availability, Atmos. Meas. Tech., 7, 1395-1427, doi:10.5194/amt-7-1395-2014, 2014.

Johnson, B. J., Oltmans, S. J., Vömel, H., Smit, H. G. J., Deshler, T., and Kroger, C.: Electrochemical concentration cell (ECC) ozone sonde pump efficiency measurements and tests on the sensitivity to ozone of buffered and unbuffered ECC sensor cathode solutions, J. Geophys. Res., 107, 4393, doi:10.1029/2001JD000557, 2002.

Levelt, P. F., Hilsenrath, E., Leppelmeier, G. W., van den Oord, G. B. J., Bhartia, P. K., Tamminen, J., de Haan, J. F., and Veefkind, J. P.: Science objectives of the Ozone Monitoring Instrument, IEEE Trans. Geosci. Remote Sens., 44, 1199-1208, 2006.

Llewellyn, E. J., Lloyd, N. D., Degenstein, D. A., Gattinger, R. L., Petelina, S. V., Bourassa, A. E., Wiensz, J. T., Ivanov, E. V., McDade, I. C., Solheim, B. H., McConnell, J. C., Haley, C. S., von Savigny, C., Sioris, C. E., McLinden, C. A., Griffioen, E., Kaminski, J., Evans, W. F. J., Puckrin, E., Strong, K., Wehrle, V., Hum, R. H., Kendall, D. J. W., Matsushita, J., Murtagh, D. P., Brohede, S., Stegman, J., Witt, G., Barnes, G., Payne, W. F., Piché, L., Smith, K., Warshaw, G., Deslauniers, D.-L., Marchand, P., Richardson, E. H., King, R. A., Wevers, I., McCreath, W., Kyrölä, E., Oikarinen, L., Leppelmeier, G. W., Auvinen, H., Mégie, G., Hauchecorne, A., Lefèvre, F., de La Nöe, J., Ricaud, P., Frisk, U., Sjoberg, F., von Schéele, F., and Nordh, L.: The OSIRIS instrument on the Odin spacecraft, Can. J. Phys., 82, 411-422, doi:10.1139/P04-005, 2004.

Matthews, E.: Global vegetation and land use: new high resolution data bases for climate studies, J. Appl. Meteorol., 22, 474-487, 1983.

McCormick, M. P., Zawodny, J. M., Viega, R. E., Larson, J. C., and Wang, P. H.: An overview of SAGE I and II ozone measurements, Planet. Space Sci., 37, 1567-1586, doi:10.1016/00320633(89)90146-3, 1989.

McElroy, C. T., Nowlan, C. R., Drummond, J. R., Bernath, P. F., Barton, D. V., Dufour, D. G., Midwinter, C., Hall, R. B., Ogyu, A., Ullberg, A., Wardle, D. I., Kar, J., Zou, J., Nichitiu, F., Boone, C. D., Walker, K. A., and Rowlands, N.: The ACE-MAESTRO instrument on SCISAT: Description, performance, and preliminary results, Appl. Optics, 46, 4341-4356, 2007.

Mieruch, S., Weber, M., von Savigny, C., Rozanov, A., Bovensmann, H., Burrows, J. P., Bernath, P. F., Boone, C. D., Froidevaux, L., Gordley, L. L., Mlynczak, M. G., Russell III, J. M., Thomason, L. W., Walker, K. A., and Zawodny, J. M.: Global and long-term comparison of SCIAMACHY limb ozone profiles with correlative satellite data (2002-2008), Atmos. Meas. Tech., 5, 771-788, doi:10.5194/amt-5-771-2012, 2012.

Platt, U.: Differential optical absorption spectroscopy (DOAS), Chem. Anal. Series, 127, 27-83, 1994.

Rahpoe, N., von Savigny, C., Weber, M., Rozanov, A.V., Bovensmann, H., and Burrows, J. P.: Error budget analysis of SCIAMACHY limb ozone profile retrievals using the SCIATRAN model, Atmos. Meas. Tech., 6, 2825-2837, doi:10.5194/amt-62825-2013, 2013.
Rahpoe, N., Weber, M., Rozanov, A. V., Weigel, K., Bovensmann, H., Burrows, J. P., Laeng, A., Stiller, G., von Clarmann, T., Kyröla, E., Sofieva, V. F., Tamminen, J., Walker, K., Degenstein, D., Bourassa, A. E., Hargreaves, R., Bernath, P., Urban, J., and Murtagh, D. P.: Relative drifts and biases between six ozone limb satellite measurements from the last decade, Atmos. Meas. Tech. Discuss., 8, 3697-3728, doi:10.5194/amtd-8-3697-2015, 2015.

Read, P. L.: Theory of planetary atmospheres: an introduction to their physics and chemistry. (2nd edition). By J. W. Chamberlain and D. M. Hunten. International Geophysics Series, 36. Academic Press Inc. Florida. 1987. Pp. 481. £41.50, Q. J. Roy. Meteor. Soc., 114, 551-552, doi:10.1002/qj.49711448014, 1988.

Rohen, G. J., von Savigny, C., Llewellyn, E. J., Kaiser, J. W., Eichmann, K.-U., Bracher, A., Bovensmann, H., and Burrows, J. P.: First results of ozone profiles between 35 and $65 \mathrm{~km}$ retrieved from SCIAMACHY limb spectra and observations of ozone depletion during the solar proton events in Oct./Nov. 2003, Adv. Space Res., 37, 2263-2268, 2006.

Rozanov, A., Bovensmann, H., Bracher, A., Hrechanyy, S., Rozanov, V., Sinnhuber, M., Stroh, F., and Burrows, J. P.: $\mathrm{NO}_{2}$ and $\mathrm{BrO}$ vertical profile retrieval from SCIAMACHY limb measurements: sensitivity studies, Adv. Space Res., 36, 846-854, 2005.

Rozanov, A., Eichmann, K.-U., von Savigny, C., Bovensmann, H., Burrows, J. P., von Bargen, A., Doicu, A., Hilgers, S., GodinBeekmann, S., Leblanc, T., and McDermid, I. S.: Comparison of the inversion algorithms applied to the ozone vertical profile retrieval from SCIAMACHY limb measurements, Atmos. Chem. Phys., 7, 4763-4779, doi:10.5194/acp-7-4763-2007, 2007.

Rozanov, A., Kühl, S., Doicu, A., McLinden, C., Puķı te, J., Bovensmann, H., Burrows, J. P., Deutschmann, T., Dorf, M., Goutail, F., Grunow, K., Hendrick, F., von Hobe, M., Hrechanyy, S., Lichtenberg, G., Pfeilsticker, K., Pommereau, J. P., Van Roozendael, M., Stroh, F., and Wagner, T.: BrO vertical distributions from SCIAMACHY limb measurements: comparison of algorithms and retrieval results, Atmos. Meas. Tech., 4, 1319-1359, doi:10.5194/amt-4-1319-2011, 2011.

Rozanov, V., Rozanov, A., Kokhanovsky, A., and Burrows, J.: Radiative transfer through terrestrial atmosphere and ocean: software package SCIATRAN, J. Quant. Spectrosc. Ra., 133, 13-71, 2014.

Russell III, J. M., Gordley, L. L., Deaver, L. E., Thompson, R. E., and Park, J. H.: An Overview of the Halogen Occultation Experiment (HALOE) and Preliminary Results, Adv. Space Res., 14, 13-20, 1994.

Sofieva, V. F., Rahpoe, N., Tamminen, J., Kyrölä, E., Kalakoski, N., Weber, M., Rozanov, A., von Savigny, C., Laeng, A., von Clarmann, T., Stiller, G., Lossow, S., Degenstein, D., Bourassa, A., Adams, C., Roth, C., Lloyd, N., Bernath, P., Hargreaves, R. J., Urban, J., Murtagh, D., Hauchecorne, A., Dalaudier, F., van Roozendael, M., Kalb, N., and Zehner, C.: Harmonized dataset of ozone profiles from satellite limb and occultation measurements, Earth Syst. Sci. Data, 5, 349-363, doi:10.5194/essd5-349-2013, 2013.

Sonkaew, T., Rozanov, V. V., von Savigny, C., Rozanov, A., Bovensmann, H., and Burrows, J. P.: Cloud sensitivity studies for stratospheric and lower mesospheric ozone profile retrievals from mea- 
surements of limb-scattered solar radiation, Atmos. Meas. Tech., 2, 653-678, doi:10.5194/amt-2-653-2009, 2009.

Tegtmeier, S., Hegglin, M. I., Anderson, J., Bourassa, A., Brohede, S., Degenstein, D., Froidevaux, L., Fuller, R., Funke, B., Gille, J., Jones, A., Kasai, Y., Krüger, K., Kyrölä, E., Lingenfelser, G., Lumpe, J., Nardi, B., Neu, J., Pendlebury, D., Remsberg, E., Rozanov, A., Smith, L., Toohey, M., Urban, J., von Clarmann, T., Walker, K. A., and Wang, R. H. J.: SPARC Data Initiative: a comparison of ozone climatologies from international satellite limb sounders, J. Geophys. Res.-Atmos., 118, 1222912247, 2013.

Waters, J. W., Froidevaux, L., Harwood, R. S., Jarnot, R. F., Pickett, H. M., Read, W. G., Siegel, P. H., Cofield, R. E., Filipiak, M. J., Flower, D. A., Holden, J. R., Lau, G. K. K., Livesey, N. J., Manney, G. L., Pumphrey, H. C., Santee, M. L., Wu, D. L., Cuddy, D. T., Lay, R. R., Loo, M. S., Perun, V. S., Schwartz, M. J., Stek, P. C., Thurstans, R. P., Boyles, M. A., Chandra, K. M., Chavez, M. C., Chen, G. S., Chudasama, B. V., Dodge, R., Fuller, R. A., Girard, M. A., Jiang, J. H., Jiang, Y. B., Knosp, B. W., LaBelle, R. C., Lam, J. C., Lee, K. A., Miller, D., Oswald, J. E., Patel, N. C., Pukala, D. M., Quintero, O., Scaff, D. M., Van Snyder, W., Tope, M. C., Wagner, P. A., and Walch, M. J.: The Earth Observing System Microwave Limb Sounder (EOS MLS) on the Aura satellite, IEEE Trans. Geosci. Remote Sens., 44, 1075-1092, doi:10.1109/TGRS.2006.873771, 2006. 